\begin{tabular}{|c|c|c|}
\hline \multicolumn{3}{|c|}{ Jurnal Warna : Jurnal Pendidikan Dan Pembelajaran Anak Usia dini. } \\
& Maret 2020. Vol 05. No. 01 \\
\hline Received: Maret 2020 & Accepted: Maret 2020 & Published: Maret 2020 \\
\hline & Article DOI: $10.24903 /$ iw.v5i1.436 \\
\hline
\end{tabular}

\title{
PENGEMBANGAN BAHAN AJAR ASESMEN PERKEMBANGAN ANAK USIA DINI DENGAN MODEL PEMBELAJARAN PROJECT BASED LEARNING (PBL)
}

\author{
Hardiyanti Pratiwi \\ PIAUD Universitas Islam Negeri Antasari Banjarmasin \\ diyankonayuki@gmail.com
}

\begin{abstract}
Abstrak
Penelitian ini bertujuan mengembangkan bahan ajar asesmen perkembangan anak usia dini dengan menggunakan model pengembangan Dick and Carey. Hal ini mengingat begitu pentingnya asessmen dan evaluasi untuk mendukung dan memastikan keberhasilan perkembangan seluruh potensi anak usia dini, maka guru PAUD maupun orang tua harus mengakuisisi keahlian ini sebaik mungkin. Namun, pembelajaran yang hanya berfokus pada pemahaman teori tanpa disertai dengan praktik menjadi penyebab utama mahasiswa PIAUD tidak memiliki keterampilan dalam merancang instrumen dan melaksanakan asesmen. Sumber data dalam penelitian ini adalah mahasiswa PIAUD angkatan 2017 sebagai calon pengguna dan validator ahli, yang terdiri dari ahli materi dan ahli desain pembelajaran. Desain uji coba produk terdiri dari validasi ahli, uji coba perorangan, dan uji coba kelompok kecil. Hasil uji coba menunjukkan: (1) Angket dari validator ahli menyatakan tidak ada indikator yang perlu direvisi, namun ada beberapa catatan dari para ahli di luar indikator dalam angket, sehingga peneliti melakukan revisi dari catatan tersebut. (2) Terdapat beberapa saran dan masukan dari responden uji coba perorangan yang berjumlah 3 orang. Selanjutnya hasil revisi dari uji coba perorangan diuji coba lagi pada kelompok kecil. (3) Pada uji coba kelompok kecil juga terdapat beberapa catatan/ saran dari responden yang dijadikan panduan bagi peneliti untuk merevisi bahan ajar pada tahap akhir.
\end{abstract}

Kata kunci: Bahan Ajar, Asesmen, Anak Usia Dini, Project Based Learning (PBL).

\begin{abstract}
This study aims to develop teaching materials for the assessment of early childhood development using the Dick and Carey development model. This is because given the importance of assessment and evaluation to support and ensure the successful development of all potential early childhood, $P A U D$ teachers and parents must acquire this expertise as possible. However, learning that only focuses on understanding theory without being accompanied by practice is the main cause of PIAUD students not having the skills in designing instruments and carrying out assessments. The data source in this study is 2017 PIAUD students as prospective users and expert validators, consisting of material experts and learning design experts. The product trial design consists of expert validation, individual trials, and small group trials. The trial results show: (1) The questionnaire from the expert validator stated that there were no indicators that needed to be revised, but there were a number of notes from experts outside the indicators in the questionnaire, so the researcher made a revision of the notes. (2) There are several suggestions and input from individual trial respondents, amounting to 3 people. Furthermore, the revised results of individual trials were retried on small groups. (3) In the small group trial there are also some notes / suggestions from respondents which are used as a guide for researchers to revise teaching materials in the final stage.
\end{abstract}

Keywords: Teaching Materials, Assessment, Early Childhood, Project Based Learning (PBL). 


\begin{tabular}{|c|c|c|}
\hline \multicolumn{3}{|c|}{ Jurnal Warna : Jurnal Pendidikan Dan Pembelajaran Anak Usia dini. } \\
Maret 2020. Vol 05. No. 01 \\
\hline Received: Maret 2020 & Accepted: Maret 2020 & Published: Maret 2020 \\
\hline & Article DOI: 10.24903/jw.v5i1.436 \\
\hline
\end{tabular}

\section{PENDAHULUAN}

Program pendidikan anak usia dini ditujukan untuk membantu anak mendapatkan segala dukungan dalam proses mencapai potensi mereka. Merancang dan mengevaluasi dampak program pendidikan anak usia dini membutuhkan pemahaman tentang cara mengukur dan melacak perkembangan anak. Karena hal inilah keahlian dalam melaksanakan asessmen dan evaluasi harus dikuasai, tidak hanya oleh guru PAUD, tetapi juga orang tua. Mengingat begitu pentingnya asessmen dan evaluasi untuk mendukung dan memastikan keberhasilan perkembangan seluruh potensi anak usia dini, maka guru PAUD maupun orang tua harus mengakuisisi keahlian ini sebaik mungkin. Prodi PIAUD UIN Antasari merupakan wadah bagi mahasiswa dalam menggali ilmuilmu kePAUDan, tidak terkecuali ilmu dalam melakukan asesmen perkembangan anak usia dini yang tertuang dalam mata kuliah Asesmen dan Evaluasi PAUD.

Dari observasi dan identifikasi yang peneliti lakukan kepada mahasiswa prodi PIAUD Fakultas Tarbiyah dan Keguruan UIN Antasari Banjarmasin yang telah mengikuti mata kuliah asessmen dan evaluasi AUD, terdapat beberapa permasalahan, antara lain:

1. Proses perkuliahan monoton berupa presentasi makalah dan tanya jawab. Setiap pertemuan, banyak pertanyaan esensial yang tidak mampu dijawab oleh pemakalah.

2. Bahan materi makalah memang tidak dibatasi, namun kebanyakan dari mahasiswa mengambil bahan makalah mereka dari situs-situs internet tanpa memilah dan memperhatikan kredibilitas situs tersebut.

3. Taksonomi kognitif yang ditetapkan pada mata kuliah tersebut hanya terbatas pada taksonomi level 2, yaitu kemampuan untuk menjelaskan.

4. Level taksonomi kognitif berimplikasi pada bentuk soal middle atau final test yang hanya menuntut penjelasan secara teoritis.

Pembelajaran yang hanya berfokus pada pemahaman teori tanpa disertai dengan praktik menjadi penyebab utama mahasiswa PIAUD tidak memiliki keterampilan dalam merancang instrumen dan melaksanakan asesmen. Idealnya, profil lulusan sarjana tidak hanya menguasai pengetahuan, tetapi juga kemampuan kerja. 


\begin{tabular}{|c|c|c|}
\hline \multicolumn{3}{|c|}{ Jurnal Warna : Jurnal Pendidikan Dan Pembelajaran Anak Usia dini. } \\
Maret 2020. Vol 05. No. 01 \\
\hline Received: Maret 2020 & Accepted: Maret 2020 & Published: Maret 2020 \\
\hline & Article DOI: 10.24903/jw.v5i1.436 \\
\hline
\end{tabular}

Pembelajaran yang berpusat pada dosen mengakibatkan komunikasi satu arah sehingga tidak mendorong critical thinking dan mahasiswa menjadi pasif. Akhirnya, mahasiswa menjadi miskin pengalaman belajar dan akuisisi kemampuan berjalan lambat. Karena itu, pendekatan pembelajaran student centered learning (SCL) sangat diperlukan agar proses pembelajaran tidak hanya berkutat pada pemahaman teoritis, tetapi juga akuisisi kemampuan praktis. Salah satu model pembelajaran dengan pendekatan SCL yang menekankan akuisisi kemampuan kerja adalah Project Based Learning (PBL).

Berdasarkan pemaparan ini, maka peneliti berkepentingan untuk melakukan penelitian pengembangan bahan ajar asesmen dan evaluasi AUD berbasis proyek bagi mahasiswa prodi PIAUD Fakultas Tarbiyah UIN Antasari Banjarmasin.

\section{METODE PENELITIAN}

Penelitian ini merupakan penelitian pengembangan dengan berpedoman pada model Dick \& Carey. Adapun yang menjadi sumber data dalam penelitian ini adalah mahasiswa PIAUD UIN Antasari angkatan 2017 sebagai calon pengguna dan validator ahli, yang terdiri dari ahli materi (tentang evaluasi) dan ahli desain pembelajaran. Desain uji coba produk terdiri dari validasi ahli, uji coba perorangan, dan uji coba kelompok kecil.

\section{HASIL PENELITIAN}

Berikut ini adalah langkah-langkah pengembangan bahan ajar asesmen dengan pendekatan project based learning model Dick dan Carey:

\section{a. Identifikasi tujuan pembelajaran berdasarkan analisis kebutuhan.}

Berdasarkan analisis kinerja, penilaian kebutuhan (needs assesment), dan dari pengalaman praktis di lapangan, maka tujuan pembelajaran umum dalam pengembangan bahan ajar ini adalah mahasiswa mampu melakukan asesmen untuk anak usia dini. Penetuan Tujuan pembelajaran umum tersebut juga mengacu pada capaian pembelajaran mata kuliah Asesmen dan Evaluasi PAUD pada Rencana Pembelajaran Semester sesuai Kerangka Kualifikasi Nasional Indonesia.

\section{b. Melakukan analisis instruksional.}

1) Membedakan asesmen formal dan informal

2) Menjelaskan teknik-teknik dalam melakukan asesemen. 


\begin{tabular}{|c|c|c|}
\hline \multicolumn{3}{|c|}{ Jurnal Warna : Jurnal Pendidikan Dan Pembelajaran Anak Usia dini. } \\
& Maret 2020. Vol 05. No. 01 \\
\hline Received: Maret 2020 & Accepted: Maret 2020 & Published: Maret 2020 \\
\hline & Article DOI: $10.24903 /$ iw.v5i1.436 \\
\hline
\end{tabular}

3) Melakukan asesmen kepada anak usia dini dengan berbagai teknik sesuai dengan karakteristik aspek perkembangan

4) Merancang instrumen penilaian sederhana

5) Menunjukkan sikap bertanggung jawab atas pekerjaannya

\section{c. Menentukan perilaku yang}

diharapkan dan karakteristik
pembelajar.

\begin{tabular}{|c|c|}
\hline Data\& Teknik & Karakateristik Pembelajar \\
\hline $\begin{array}{l}\text { Entry skill/ } \\
\text { keterampilan } \\
\text { masukan } \\
\text { Angket dan } \\
\text { observasi }\end{array}$ & $\begin{array}{l}\text { Hampir semua mahasiswa belum } \\
\text { pernah melakukan kegiatan } \\
\text { asesmen perkembangan untuk } \\
\text { anak usia dini } \\
\text { Target keterampilannya adalah } \\
\text { mahasiswa terampil dalam } \\
\text { melakukan asesmen terhadap } \\
\text { perkembangan anak usia dini }\end{array}$ \\
\hline $\begin{array}{l}\text { Prior knowledge } \\
\text { of topic areal } \\
\text { Pengetahuan } \\
\text { sebelumnya } \\
\text { Angket dan } \\
\text { Pretest }\end{array}$ & $\begin{array}{l}45 \% \text { responden mengatakan } \\
\text { belum mengetahui tentang } \\
\text { asesmen perkembangan anak usia } \\
\text { dini, sedangkan } 54 \% \text { sudah } \\
\text { sedikit mengetahui tentang } \\
\text { pengertian asesmen, namun } \\
\text { belum mengetahi tentang teknik- } \\
\text { teknik dalam melakukan asesmen } \\
\text { dan belum mengetahui tentang } \\
\text { asesmen formal dan informal. } \\
\text { Dari hasil prestest dapat dilihat } \\
\text { pegetahuan mahasiswasa masih } \\
\text { sebatas pengertian asesmen, } \\
\text { belum memahami tentang } \\
\text { asesmen formal da informal }\end{array}$ \\
\hline $\begin{array}{l}\text { Attitude toward } \\
\text { content/Sikap } \\
\text { terhadap conten/ } \\
\text { materi }\end{array}$ & $\begin{array}{l}100 \% \text { responden mengaku sangat } \\
\text { tertarik untuk mempelajari } \\
\text { tentang asesmen, karena mereka } \\
\text { meyakini bahwa asesmen } \\
\text { merupakan bagian yang tidak } \\
\text { terpisahkan dari suatu proses } \\
\text { pembelajaran. Asesmen juga } \\
\text { merupakan cara agar pendidik } \\
\text { mengetahui perkembangan anak. }\end{array}$ \\
\hline
\end{tabular}

\begin{tabular}{|c|c|}
\hline & $\begin{array}{l}\text { Hasil observasi peneliti juga } \\
\text { menunjukkan bahwa mahasiswa } \\
\text { terlihat antusias dalam berdiskusi } \\
\text { atau bertanya tentang proses } \\
\text { asesmen }\end{array}$ \\
\hline $\begin{array}{l}\text { Motivation for } \\
\text { instruction/ } \\
\text { Motivasi dalam } \\
\text { pelajaran }\end{array}$ & $\begin{array}{l}\text { 100\% responden memiliki } \\
\text { motivasi yang bagus untuk } \\
\text { mengikuti mata kuliah asesmen, } \\
\text { mereka mengaku meyukai materi- } \\
\text { materi yang akan dibahas pada } \\
\text { mata kuliah asesmen. Hal ini } \\
\text { tentu menjadi modal bagi faktor } \\
\text { pendukung proses pembelajaran } \\
\text { terkait keaktivan mahasiswa }\end{array}$ \\
\hline $\begin{array}{l}\text { Educational and } \\
\text { ability level/ } \\
\text { Level } \\
\text { pendidikan dan } \\
\text { kemampuan } \\
\text { Angket } \\
\text { Observasi }\end{array}$ & $\begin{array}{l}\text { Level/ kategori pendidikan } \\
\text { responden sangat bervariasi, ada } \\
\text { yang berasal dari pondok } \\
\text { pesantren, SMA umum, dan dari } \\
\text { Madrasah Aliyah. Level ini tentu } \\
\text { juga menjadikan kebiasaan/ sikap } \\
\text { yang berbeda-beda dari para } \\
\text { responden, karena pada umumnya } \\
\text { sistem pembelajaran antara } \\
\text { pondok pesantren, SMA umum, } \\
\text { dan Madrasah Aliyah ada } \\
\text { beberapa perbedaan. } \\
\text { IPK responden juga sangat } \\
\text { bervariasi, ini juga menunjukkan } \\
\text { adanya keberagaman dari } \\
\text { responden. Namun tidak ada IPK } \\
\text { yang di bawah 3,00. Variasi IPK } \\
\text { berkisar dari 3,00 sampai dengan } \\
\text { 3,90 }\end{array}$ \\
\hline $\begin{array}{l}\text { General } \\
\text { Learning } \\
\text { preferences/ } \\
\text { Kecenderungan } \\
\text { belajar secara } \\
\text { umum } \\
\text { Angket } \\
\text { Observasi }\end{array}$ & $\begin{array}{l}\text { 77\% Responden mengaku sudah } \\
\text { terbiasa melakukan diskusi } \\
\text { dengan teman sebaya dalam } \\
\text { pembelajaran, sedangkan } 23 \% \\
\text { nya mengaku belum terbiasa. } \\
\text { Beberapa responden menyukai } \\
\text { cara belajar melalui/ dengan: } \\
\text { - } \quad \text { penjelasan yang detail dari } \\
\text { dosen ataupun teman lain } \\
\text { yang lebih menguasai } \\
\text { merangkum kembali/ } \\
\text { menjawab soal-soal dari apa } \\
\text { yang telah dibaca dengan } \\
\text { kalimat sendiri } \\
\text { mengaitkan teori dengan } \\
\text { contoh-contoh nyata dalam } \\
\text { kehidupan sehari-hari } \\
\text { diskusi kelompok } \\
\text { ada kegiatan praktek/ } \\
\text { observasi lapangan agar tidak } \\
\text { bosan dan lebih memahami } \\
\text { materi }\end{array}$ \\
\hline
\end{tabular}




\begin{tabular}{|c|c|c|}
\hline \multicolumn{3}{|c|}{ Jurnal Warna : Jurnal Pendidikan Dan Pembelajaran Anak Usia dini. } \\
& Maret 2020. Vol 05. No. 01 \\
\hline Received: Maret 2020 & Accepted: Maret 2020 & Published: Maret 2020 \\
\hline & Article DOI: $10.24903 /$ iw.v5i1.436 \\
\hline
\end{tabular}

\begin{tabular}{|l|l|}
\hline & \multicolumn{1}{|c|}{$\begin{array}{l}\text { ada selingan game dalam } \\
\text { belajar }\end{array}$} \\
\hline $\begin{array}{l}\text { General group } \\
\text { characteristic/ } \\
\text { karakteristik } \\
\text { secara umum }\end{array}$ & $\begin{array}{l}\text { Secara umum, sebagian besar } \\
\text { responden berasal dari suku } \\
\text { Banjar, walaupun ada beberapa } \\
\text { yang berasal dari suku Jawa, dan } \\
\text { Dayak. }\end{array}$ \\
Angket & $\begin{array}{l}\text { Secara ekonomi, responden } \\
\text { berada pada tingkat menengah } \\
\text { dan menengah ke bawah, } \\
\text { berdasarkan biaya UKT, yaitu 9\% } \\
\text { Rp.400.000, 40\% Rp. 800.000, }\end{array}$ \\
& $37 \%$ Rp. 1,200.000, dan 14\% Rp. \\
& 1.500 .000 \\
\hline
\end{tabular}

\section{d. Menentukan sasaran kinerja.}

Berdasarkan pada tujuan pembelajaran umum dan analisis pembelajaran yang telah didapatkan sebelumnya maka sasaran kinerja atau tujuan instruksional khususnya ialah sebagai berikut:

1) Melalui kegiatan kunjungan lapangan ke lembaga PAUD dan kegiatan library tour, mahasiswa mampu membedakan asesmen formal dan informal

2) Melalui kegiatan kunjungan lapangan ke lembaga PAUD dan kegiatan library tour, mahasiswa mampu menjelaskan teknik-teknik dalam asesmen

3) Melalui praktek lapangan, mahasiswa mampu melakukan asesmen di TPA/KB/ TK/RA

4) Melalui diskusi kelompok, mahasiswa mampu merancang instrumen sederhana
5) Melalui penugasan lapangan, mahasiswa mampu bertanggungjawab terhadap tugasnya sampai selesai

\section{e. Mengembangkan}

Instrumen

\section{Penilaian.}

Berdasarkan tujuan yang telah ditetapkan, peneliti mengembangkan penilaian yang sesuai untuk mengukur kemampuan mahasiswa dalam pencapaian tujuan. Karena model pembelajaran berbasis proyek bertujuan untuk menciptakan sebuah produk, maka penilaian harus disesuaikan dengan tujuan tersebut beserta proses dalam merealisasikan tujuan. Deskripsi lengkap mengenai instrumen penilaian ada pada produk bahan ajar (lampiran). Adapun gambarannya bisa dilihat pada tabel berikut:

\begin{tabular}{|l|l|}
\hline $\mathbf{N}$ & \multicolumn{1}{|c|}{ Instrumen Penilaian } \\
\hline o & \multicolumn{1}{|c|}{$\begin{array}{l}\text { Tertulis: } \\
\text { Laporan kegiatan yang berisi tentang deskripsi } \\
\text { tempat kunjungan, hasil wawancara tentang } \\
\text { materi, kesimpulan tentang materi berdasarkan } \\
\text { library tour dan kunjungan lapangan. } \\
\text { 3. Lisan : } \\
\text { Mahasiswa mampu membedakan asesmen } \\
\text { formal dan informal. (lembar penilaian } \\
\text { terlampir di bahan ajar) }\end{array}$} \\
\hline $\begin{array}{l}\text { 1. Tertulis: } \\
\text { Laporan kegiatan yang berisi tentang deskripsi } \\
\text { tempat kunjungan, hasil wawancara tentang } \\
\text { materi, kesimpulan tentang materi berdasarkan } \\
\text { library tour dan kunjungan lapangan. } \\
\text { 2. Lisan : } \\
\text { Mahasiswa mampu menjelaskan setiap teknik- } \\
\text { teknik dalam melakukan penilaian beserta } \\
\text { ilustrasi contohnya. (lembar penilaian } \\
\text { terlampir di bahan ajar) }\end{array}$ \\
\hline
\end{tabular}




\begin{tabular}{|c|c|c|}
\hline \multicolumn{3}{|c|}{ Jurnal Warna : Jurnal Pendidikan Dan Pembelajaran Anak Usia dini. } \\
& Maret 2020. Vol 05. No. 01 \\
\hline Received: Maret 2020 & Accepted: Maret 2020 & Published: Maret 2020 \\
\hline & Article DOI: $10.24903 /$ iw.v5i1.436 \\
\hline
\end{tabular}

\begin{tabular}{|c|c|}
\hline 3 & $\begin{array}{l}\text { 1. Unjuk Kerja: } \\
\text { Melakukan asesmen terhadap perkembangan } \\
\text { anak, kemudian menuliskan kesimpulan } \\
\text { tentang hasil asesmen yang dikaitkan dengan } \\
\text { teori perkembangan anak sesuai usianya, serta } \\
\text { kendala-kendala yang dihadapi saat proses } \\
\text { asesmen. } \\
\text { 2. Lisan : } \\
\text { Mahasiswa mampu memperesentasikan proses } \\
\text { saat melakukan asesmen kepada anak usia } \\
\text { dini.. }\end{array}$ \\
\hline 4 & $\begin{array}{l}\text { 1. Produk: } \\
\text { Produk berupa instrumen penilaian sederhana }\end{array}$ \\
\hline 5 & $\begin{array}{l}\text { 1. Observasi: } \\
\text { Kegiatan mahasiswa dalam mengerjakan } \\
\text { setiap tugas (instrumen untuk setiap } \\
\text { penugasan) }\end{array}$ \\
\hline
\end{tabular}

\section{f. Mengembangkan}

strategi

pembelajaran.

Strategi yang dikembangkan

berdasarkan pendekatan student centered learning. Student centered learning atau

Pembelajaran yang berpusat pada siswa secara luas diartikan sebagai metode yang mengalihkan fokus pengajaran dari dosen ke mahasiswa untuk mengembangkan otonomi dan kemandirian pelajar (Jones:2007). Dalam ruang belajar yang berpusat pada mahasiswa, mereka memilih sendiri topik yang akan dipelajari, cara belajar, hingga mengevaluasi pembelajaran mereka sendiri (Hannafin:2010)

Tujuan instruksional pertama (mampu membedakan asesmen formal dan informal) digunakan strategi library tour, study tour, dan reading guide dengan langkah-langkah sebagai berikut:
1) Mahasiswa dikelompokkan dalam 3 orang tiap kelompoknya

2) Mahasiswa ditugaskan untuk melakukan study tour dengan mengunjungi lembaga PAUD, baik TK, RA, maupun KB

3) Dosen memberikan kisi-kisi pertanyaan kepada semua kelompok untuk dicari jawabannya di tempat yang dituju.

4) Mahasiswa menggali tentang materi di tempat yang dituju, dengan observasi maupun wawancara kepada guru maupun kepala lembaga.

5) Selanjutnya mahasiswa ditugaskan untuk melakukan library tour (penelusuran bahan pustaka) (masih dengan kelompok yang sama)

6) Dosen memberikan beberapa kisi-kisi judul bahan bacaan yang akan dipelajari

7) Mahasiswa membaca beberapa referensi untuk melengkapi laporan dari hasil kunjungan ke lembaga PAUD.

8) Mahasiswa menuliskan laporan hasil library tour dan kunjungan lapangan di lembaga PAUD dengan suatu kesimpulan yang berkaitan dengan materi, yaitu metode-metode dalam melakukan asesmen 


\begin{tabular}{|c|c|c|}
\hline \multicolumn{3}{|c|}{ Jurnal Warna : Jurnal Pendidikan Dan Pembelajaran Anak Usia dini. } \\
Maret 2020. Vol 05. No. 01 \\
\hline Received: Maret 2020 & Accepted: Maret 2020 & Published: Maret 2020 \\
\hline & Article DOI: 10.24903/jw.v5i1.436 \\
\hline
\end{tabular}

9) Masing-masing kelompok mempresentasikan hasil laporannya

10) Dosen melakukan tambahantambahan maupun klarifikasi

Untuk tujuan instruksional kedua (mampu menjelaskan teknik-teknik dalam melakukan asesmen) digunakan strategi reading guide dengan langkah-langkah sebagai berikut:

1) Mahasiswa dikelompokkan dalam 3 orang tiap kelompoknya

2) Mahasiswa ditugaskan untuk mengunjungi lembaga PAUD, baik TK, RA, maupun KB

3) Dosen memberikan kisi-kisi pertanyaan kepada semua kelompok untuk dicari jawabannya di tempat yang dituju.

4) Mahasiswa menggali tentang materi di tempat yang dituju, dengan observasi maupun wawancara kepada guru maupun kepala lembaga.

5) Selanjutnya mahasiswa ditugaskan untuk melakukan library tour (penelusuran bahan pustaka) (masih dengan kelompok yang sama)

6) Dosen memberikan beberapa kisi-kisi judul bahan bacaan yang akan dipelajari

7) Mahasiswa membaca beberapa referensi untuk melengkapi laporan dari hasil kunjungan ke lembaga PAUD.

8) Mahasiswa menuliskan laporan hasil library tour dan kunjungan lapangan di lembaga PAUD dengan suatu kesimpulan yang berkaitan dengan materi, yaitu metode-metode dalam melakukan asesmen

9) Masing-masing kelompok mempresentasikan hasil laporannya

10) Dosen melakukan tambahantambahan maupun klarifikasi

Untuk tujuan instruksional ketiga (Melakukan asesmen dengan berbagai teknik) digunakan strategi practice rehearsal dengan langkah-langkah sebagai berikut:

1) Mahasiswa akan bekerja dalam kelompok (maksimal 3 orang dalam 1 kelompok)

2) Mahasiswa memilih metode asesmen yang akan dipraktekkan di lembaga PAUD

3) Sebelum ke lapangan, mahasiswa menyusun dulu rancangan atau rencana persiapannya untuk terjun ke lapangan

4) Mahasiswa memilih lembaga PAUD yang akan dituju.

5) Mahasiswa mengonsultasikan hasil rancangannya kepada dosen 


\begin{tabular}{|c|c|c|}
\hline \multicolumn{3}{|c|}{ Jurnal Warna : Jurnal Pendidikan Dan Pembelajaran Anak Usia dini. } \\
Maret 2020. Vol 05. No. 01 \\
\hline Received: Maret 2020 & Accepted: Maret 2020 & Published: Maret 2020 \\
\hline & Article DOI: 10.24903/jw.v5i1.436 \\
\hline
\end{tabular}

6) Mahasiswa melakukan asesmen kepada anak-anak di tempatnya masing-masing

7) Mahasiswa menuliskan laporan hasil kegiatan dan mempresentasikannya

8) Dosen melakukan klarifikasi.

Untuk tujuan instruksional keempat (Merancang instrumen untuk melakukan asesmen) digunakan strategi the power of two dengan langkah-langkah sebagai berikut:

1. Mahasiswa bejerja dalam kelompok yang terdiri dari 2 orang perkelompok.

2. Mahasiswa ditugaskan untuk mencari beberapa contoh instrumen asesmen perkembangan anak usia dini dari berbagai sumber, bisa dari skripsi, tesis, jurnal, internet, dan lain-lain.

3. Mahasiswa mempelajari, membandingkan dan mendiskusikan beberapa contoh instrumen tersebut dengan teman satu kelompok.

4. Mahasiswa mempelajari cara-cara merancang instrumen asesmen dalam buku-buku asesmen.

5. Mahasiswa merancang instrumen penilaian sederhana tentang asesmen perkembangan anak usia dini

6. Mahasiswa menukarkan hasil instrumen yang telah dibuat dengan teman di kelompok lain untuk diperiksa. Masing-masing kelompok memberikan catatan tentang instrumen yang dirancang oleh kelompok lain

7. Mahasiswa merevisi hasil pekerjaannya jika ada saran dan perbaikan.

Student centered learning mengharuskan instruktur memiliki kejelian dalam melihat keunikan dan kelebihan masing-masing mahasiswa. Mereka harus menyadari bahwa mahasiswa memiliki gaya belajar yang berbeda, memiliki kemampuan dan bakat yang berbeda, kemajuan belajar yang bervariasi hingga tahap perkembangan yang tidak sama antara satu dengan lainnya. Dengan pendekatan ini, pembelajaran dapat menjadi proses konstruktif yang relevan dan bermakna bagi mahasiswa untuk mengaitkan pengetahuan dan pengalaman yang terdahulu dengan pelajaran yang baru diterimanya. Untuk menyukseskan hal tersebut, lingkungan belajar harus didesain agar dapat berfungsi semaksimal mungkin untuk mendukung interaksi positif antar mahasiswa sehingga mereka dapat merasa nyaman, dihargai, diakui dan dihormati. Pada gilirannya, mereka dapat menjalani proses pembelajaran secara alami dan 


\begin{tabular}{|c|c|c|}
\hline \multicolumn{3}{|c|}{ Jurnal Warna : Jurnal Pendidikan Dan Pembelajaran Anak Usia dini. } \\
Maret 2020. Vol 05. No. 01 \\
\hline Received: Maret 2020 & Accepted: Maret 2020 & Published: Maret 2020 \\
\hline & Article DOI: 10.24903/jw.v5i1.436 \\
\hline
\end{tabular}

memaksimalkan potensi masing-masing dalam menguasai materi pembelajaran.

Ruang kelas dalam pendekatan pembelajaran yang berpusat pada mahasiswa membutuhkan perubahan peran dan tanggung jawab mahasiswa dan instruktur dalam hal strategi pembelajaran dan proses belajar itu sendiri. Mahasiswa memiliki keleluasaan dalam menguasai ruang kelas dalam rangka melakukan individualisasi untuk memberdayakan segala potensi dan kekhasan yang mereka miliki dalam mengarungi proses pembelajaran, interaksi dengan mahasiswa lainnya dan integrasi keilmuan yang diterimanya dengan keilmuan yang telah dikuasainya (Moffet:1992).

Pembelajaran yang berpusat pada mahasiswa memiliki implikasi yang halus tetapi mendalam bagi instruktur. Untuk bergerak ke arah model baru ini, instruktur harus bersedia untuk menekankan pembelajaran sambil berbagi kekuatan dengan mahasiswa di kelas (Barr:1995). Ini dapat dilakukan dengan bijaksana melalui perencanaan dan penggunaan langkah-langkah tambahan. Pertama, instruktur dapat membantu mahasiswa menentukan sasaran untuk diri mereka sendiri dan dapat menawarkan kegiatan yang diarahkan sendiri di mana para pembelajar dapat membangun kepercayaan diri dan keterampilan belajar mereka. Hasilnya, mahasiswa menjadi termotivasi untuk mengambil kendali yang lebih besar terhadap pembelajaran mereka, dan instruktur mendapatkan kepercayaan dalam mengelola lingkungan baru.

Pembelajaran Berbasis Proyek adalah model pembelajaran yang memfokuskan pada konsep utama suatu disiplin ilmu, melibatkan pebelajar dalam kegiatan pemecahan masalah melalui tugas, memberi peluang untuk bekerja secara otonom mengkonstruksi pengetahuan sendiri, dan puncaknya menghasilkan sebuah produk (Ngalimun:2014). Lebih lanjut, Thomas, dkk., menyatakan bahwa Pembelajaran Berbasis Proyek merupakan model pembelajaran yang memberikan kesempatan kepada guru untuk mengelola pembelajaran di kelas dengan melibatkan kerja proyek (Wena:2008).

Dalam beberapa tahun terakhir, peralihan pendekatan pembelajaran tradisional kepada pembelajaran yang berpusat pada mahasiswa terlihat sangat massif. Kendali pembelajaran bergerak dari instruktur ke mahasiswa. Instruktur memberikan arahan kepada mahasiswa tentang apa yang mereka pelajari dan bagaimana pembelajaran itu seharusnya 


\begin{tabular}{|c|c|c|}
\hline \multicolumn{3}{|c|}{ Jurnal Warna : Jurnal Pendidikan Dan Pembelajaran Anak Usia dini. } \\
Maret 2020. Vol 05. No. 01 \\
\hline Received: Maret 2020 & Accepted: Maret 2020 & Published: Maret 2020 \\
\hline & Article DOI: 10.24903/jw.v5i1.436 \\
\hline
\end{tabular}

berlangsung dengan mengakomodir perbedaan individu dalam latar belakang, minat, kemampuan dan pengalaman mahasiswa (McCombs:1997). Selebihnya, peran instruktur adalah mendorong mahasiswa untuk lebih banyak menghasilkan penemuan-penemuan berdasarkan tugas nyata dan belajar satu sama lainnya.

Salah satu model pembelajaran yang menjadikan mahasiswa sebagai pusat dengan pendekatan kelas yang dinamis adalah Project-based learning (PBL). Melalui model ini, mahasiswa memperoleh pengetahuan yang lebih mendalam berdasarkan eksplorasi suatu masalah atau pertanyaan secara aktif dan tantangan dari dunia nyata.

Thomas Markham mendeskripsikan pembelajaran berbasis proyek (PBL) sebagai model pembelajaran yang mengintegrasikan penguasaan pengetahuan dan kemampuan kerja (keterampilan) (Markham:2011).. Pembelajaran berbasis proyek (PBL) adalah bentuk pembelajaran yang berpusat pada mahasiswa yang didasarkan pada tiga prinsip konstruktivis: pembelajaran adalah konteks-spesifik, mahasiswa terlibat aktif dalam proses pembelajaran dan mereka mencapai tujuan mereka melalui interaksi sosial dan berbagi pengetahuan dan pemahaman antar mahasiswa. Pembelajaran berbasis proyek (Cocco:2006) dimuali dari sebuah pertanyaan atau permasalahan kontekstual yang mengarahkan mahasiswa untuk melakukan identifikasi, observasi hingga praktik yang dapat menghasilkan pengalaman belajar sarat makna (Wurdinger:2007).

PBL sebagai bentuk instruksi memiliki hubungan yang jelas dengan pendekatan pedagogis lainnya, seperti pembelajaran berbasis masalah (Helle:2006). Fokus dalam keduanya adalah bagaimana mahasiswa dapat mencapai tujuan bersama melalui kolaborasi. Dalam keterlibatan mereka dengan proyek, mahasiswa dapat menghadapi masalah yang perlu ditangani untuk membangun dan menyajikan produk akhir untuk memenuhi pertanyaan instruksional. Perbedaan utama antara keduanya adalah dalam pembelajaran berbasis masalah, mahasiswa difokuskan pada proses pembelajaran untuk memecahkan masalah tersebut, sedangkan PBL berujung pada sebuah produk.

\section{g. Mengembangkan dan memilih Materi pembelajaran.}




\begin{tabular}{|c|c|c|}
\hline \multicolumn{3}{|c|}{ Jurnal Warna : Jurnal Pendidikan Dan Pembelajaran Anak Usia dini. } \\
Maret 2020. Vol 05. No. 01 \\
\hline Received: Maret 2020 & Accepted: Maret 2020 & Published: Maret 2020 \\
\hline & Article DOI: $10.24903 /$ jw.v5i1.436 \\
\hline
\end{tabular}

Berikut beberapa daftar referensi yang dijadikan rujukan oleh peneliti dalam mengembangkan materi:

1) Portofolios in First Grade: Four teacher learn to use alternative assessment. Karya Benson, T. R., \& Smith, L. J.

2) A Guide to Assessment in early Childhood karya Terri Bergesso.

3) Pedoman Penilaian di Taman Kanak-kanak terbitan Direktorat Jenderal Pembinaan TK dan SD tahun 2010

4) Pedoman Penilaian Pembelajaran Pendidikan anak usia Dini terbitan kementerian Pendidikan dan Kebudayaan.

5) Understanding Assessment and Evaluation in Early Childhood Education karya Dominic F. Gullo

6) Early Child Education Today karya George S. Morisson

7) Manajemen PAUD karya Mulyasa

8) Pengembangan Instrumen Anak Usia Dini karya Harun Rasyid

9) The Use of Portofolio in Evaluation karya Sewell M Marczak

10) Evaluasi Pembelajaran TK karya Iksan Waseso

11) Tes and Assessment in Childhood Education karya Worthman S.C

12) Penilaian Perkembangan Belajar Anak TK karya Anita Yus
13) Identifikasi dan Asesmen Anak Berkebutuhan Khusus karya Imam Yuwono

\section{h. Melakukan evaluasi formatif dan revisi produk}

Pada tahap ini dilakukan empat kali uji coba yaitu: a) validasi ahli, b) uji coba perorangan, c) dan uji coba kelompok kecil

\section{1) Validasi ahli}

Validasi ahli terdiri dari ahli materi dan ahli desain pembelajaran. Ahli desain pembelajaran dimaksudkan untuk memvalidasi desain pembelajaran yang dirancang menggunakan model Project Based Learning (PBL) dilihat dari segi keilmuannya, keakuratan, strategi pembelajaran yang ada di dalamnya dan lain-lain. Adapun ahli materi berperan untuk memvalidasi materi pembelajaran dalam bahan ajar yang terkait dengan materi asesmenuntuk anak usia dini. Nama dan kualifikasi keahlian masing-masing validator dipaparkan pada tabel berikut ini: Tabel 4. Nama dan Kualifikasi Validator

\begin{tabular}{|l|l|l|}
\hline \multicolumn{1}{|c|}{ Nama } & \multicolumn{1}{|c|}{ Kualifikasi } & \multicolumn{1}{|c|}{ Validasi } \\
\hline Dr. Ani & S1 Pendidikan & Desain \\
Cahyadi, & Agama Islam & pembelajaran \\
M.Pd & S2 Teknologi & dengan model \\
& Pembelajaran & PBL \\
& S3Teknologi & \\
& Pendidikan & \\
\hline Dr. Hj. & S1 PGSD & Materi \\
Darmiyati, & S1 Pendidikan & pembelajaran \\
S.Pd.,M.Pd & Matematika & tentang \\
& S2 PAUD & asesmen \\
& S3 Evaluasi & perkembangan \\
& Pembelajaran & anak usia dini \\
\hline
\end{tabular}




\begin{tabular}{|c|c|c|}
\hline \multicolumn{3}{|c|}{ Jurnal Warna : Jurnal Pendidikan Dan Pembelajaran Anak Usia dini. } \\
Maret 2020. Vol 05. No. 01 \\
\hline Received: Maret 2020 & Accepted: Maret 2020 & Published: Maret 2020 \\
\hline & Article DOI: 10.24903/jw.v5i1.436 \\
\hline
\end{tabular}

Instrumen validasi yang digunakan untuk masing-masing validator berbedabeda sesuai keahlian validator dan target penilian yang diharapkan. Instrumen ini menggunakan skala Likert, yang mana dalam skala ini disediakan 5 pilihan jawaban yang disertai dengan saran dari validator.

Berdasarkan hasil validasi tersebut, disimpulkan bahwa materi dalam bahan ajar berada pada kategori baik. Berikut penjabarannya: pada aspek kesesuaian materi dengan indikator yang meliputi; kelengkapan materi, keluasan materi, dan kedalaman materi berada dalam kategori baik, sehingga pada poin tersebut tidak perlu dilakukan revisi. Kemudian pada aspek keakuratan materi yang meliputi; keakuratan konsep dan definisi, keakuratan istilah-istilah, juga berada dalam kategori baik, sehingga tidak perlu dilakukan revisi, sedangkan keakuratan contoh dan kasus mendapatnilai cukup baik, karena menurut validator ada beberapa contoh yang harus dirubah, yiatu pada contoh instrumen penilaian dalam kegiatan berdoa. Indikator berikutnya, keakuratan gambar dan ilustrasi mendapat nilai 3 juga yang berarti pada kategori cukup baik, berdasarkan catatan dari validator, sebaiknya gambar yang digunakan dipilih saja dari gambar-gambar orang Indonesia, bukan dari luar negeri. Maka peneliti melakukan revisi pada setiap gambar yang menggunakan orang luar negeri. Bahkan pada edisi revisi ini, peneliti menggunakan gambar-gambar dari koleksi pribadi. Validator juga menambahkan agar pada setiap gambar diberi keterangan agar lebih jelas maksudnya.

Aspek berikutnya yaitu aspek kemutakhiran materi, semua indikator berada pada kategori baik. Pada aspek kelayakan penyajian, semua indikatornya juga berada pada kategori baik, sehingga peneliti tidak melakukan revisi pada poinpoin tersebut. Validator juga memberikan beberapa catatan di luar indikator dalam angket, berikut hasil catatan dari Dr.Hj. Darmiyati, M.Pd:

a. Judul bahan ajar tertulis evaluasi dan asesmen, sebaik nya pilih salah satu saja, evaluasi atau asesmen. Dari catatan ini peneliti merevisi judul menjadi asesmen perkembangan anak usia dini, karena dari segi isi, memang lebih banyak berfokus pada proses asesmen bukan evaluasi.

b. Pada materi kedua tertulis metodemetode asesmen, bisa diganti dengan teknik penilaian. Dari catatan ini, maka peneliti mengubah kata-kata 


\begin{tabular}{|c|c|c|}
\hline \multicolumn{3}{|c|}{ Jurnal Warna : Jurnal Pendidikan Dan Pembelajaran Anak Usia dini. } \\
Maret 2020. Vol 05. No. 01 \\
\hline Received: Maret 2020 & Accepted: Maret 2020 & Published: Maret 2020 \\
\hline & Article DOI: 10.24903/jw.v5i1.436 \\
\hline
\end{tabular}

metode asesmen menjadi teknik penilaian

c. Buat kalimat sendiri sebelum mengutip. Jelaskan dulu pengertian beberapa ahli, kemudian baru disimpulkan. Dari catatan ini,penulis melakukan revisi pada materi pengertian asesmen formal dengan mengikuti saran dari validator, yaitumemulai terlebih dulu dengan kalimat sendiri, kemudian menambahkan pendapat beberapa ahli.

d. Seragamkan jenis dan ukuran font. Dari catatan ini, peneliti memperbaiki beberapa jenis font yang tidak seragam.

e. Sesuaikan contoh dengan kelompok anak PAUD. Dari catatan ini, peneliti menelusuri kembali beberapa contoh dalam bahan ajar yang tidak sesuai dengan PAUD. Terdapat penggunaan istilah seperti Ujian Nasional (UN), danbeberapa contoh lagi. Maka peneliti merevisi contoh tersebut dengan kegiatan asesmen yang sesuai dengananak usia dini.

f. Diperiksa lagi, Asesmen otentik merupakan jenis asesmen informal atau contohnya.dari catatan ini, peneliti coba menelususri lagi beberapa referensi. Dari beberapa referensi, asesmen otentik merupakan jenis dari asesmen informal.

g. Perhatikan penulisan tatabahasa sesuai kaidah bahasa Indonesia yang benar.

h. Perhatikan penggunaan paragrap pada bagian ilustrasi

i. Perhatikan penulisan Daftar pustaka sesuaikan dengan yang dikutip

Hasil angket dari Dr.Ani Cahyadi,M.Pd sebagai validator ahli desain pembelajaran adalah sebagai berikut Berdasarkan hasil validasi tersebut, dapat diketahui bahwa desain pembelajaran dalam tugas proyek pada bahan ajar telah sesuai dengan pendekatan pembelajaran Project Based Learning, karena validator mencentrang semua poinpoin indikator pada kolom 4 yang berarti berada pada kategori baik, sehingga idak perlu dilakukan revisiuntuk poin-poin tersebut. Namun, validator juga memberikan beberapa catatan di luar indikator dalam angket, berikut hasil catatan dari Dr.Ani Cahyadi, M.Pd:

a. Lay out teks: jenis font dikonsistenkan dan diseragamkan

b. Lay out tabel: grafik, dan lain-lain dibuat lebih elegan 


\begin{tabular}{|c|c|c|}
\hline \multicolumn{3}{|c|}{ Jurnal Warna : Jurnal Pendidikan Dan Pembelajaran Anak Usia dini. } \\
Maret 2020. Vol 05. No. 01 \\
\hline Received: Maret 2020 & Accepted: Maret 2020 & Published: Maret 2020 \\
\hline & Article DOI: 10.24903/jw.v5i1.436 \\
\hline
\end{tabular}

c. Disarankan dalam setiap pembahasan atau halaman ada ringkasan dibuat dalam bentuk call out supaya lebih menarik dan bisa dibaca langsung maksud dari materi yang ada.

Mempertimbangkan hasil catatan validator tersebut, maka peneliti melakukan beberapa revisi terkait layout teks dan tabel agar lebih menarik, serta menambahkan call out dalam setiap pembahasan. Call out ditampilkan dalam bentuk tulisan yang diperbesar dalam satu atau dua kalimat, dengan posisi di tengahtengah.

\section{2) Uji coba perorangan}

Dalam pelaksanaan uji coba perorangan, peneliti mengambil 3 orang sampel dari target pengguna bahan ajar, yaitu mahasiswa PIAUD semester V kelas.

Beberapa indikator yang dijadikan acuan dalam uji coba perorangan yaitu: kejelasan tulisan, kejelasan kalimat dan paragraf, kejelasan penggunaan contohcontoh, kejelasan penggunaan ilustrasi, kejelasan instruksi, membangkitkan motivasi. Di luar acuan ini, mereka juga diminta memberikan saran dan masukan terhadap finalisasi bahan ajar. Setelah produk direvisi berdasarkan catatan dari subjek uji coba perorangan, selanjutnya dilakukan uji coba kelompok kecil.
Dari data hasil uji coba perorangan tersebut, dapat diketahuipersentase jawaban dari responden. Untuk komponen kejelasan tulisan (jenis dan ukuran font), mendapat persentase $100 \%$, untuk komponen Kejelasan kalimat dan paragraph mendapat persentase $80 \%$, untuk komponen Kejelasan penggunaan contoh-contoh mendapat persentase 93,3\%, untuk komponen Kejelasan penggunaan ilustrasi mendapat persentase 93,3\%,untuk komponen Kejelasan instruksi dalam tugas proyek dan post test medapar persentase $100 \%$, dan untuk komponen Membangkitkan motivasi mendapat persentase $93,3 \%$.

Berikut beberapa catatan dan masukan dari para responden:

Responden 1 (MS):

1) Ada beberapa penggunaan kata yang menggunakan kata tidak baku, misalnya pada halaman $34,37,38$, 46, 60, dan lain-lain. Silakan cek di buku, sudah dicoret. Sebaiknya menggunakan kata-kata yang sudah baku saja.

2) Ada beberapa pengetikan yang tertinggal haruf-hurufnya, misalnya pada halaman $38,40,44,45,50,56$, dan lain-lain. Bisa diperbaiki supaya lebih nyaman dibaca 


\begin{tabular}{|c|c|c|}
\hline \multicolumn{3}{|c|}{ Jurnal Warna : Jurnal Pendidikan Dan Pembelajaran Anak Usia dini. } \\
Maret 2020. Vol 05. No. 01 \\
\hline Received: Maret 2020 & Accepted: Maret 2020 & Published: Maret 2020 \\
\hline & Article DOI: 10.24903/jw.v5i1.436 \\
\hline
\end{tabular}

3) Jika menggunakan kata bahasa asing, biasanya penulisan dimiringkan

Responden 2 (ZS):

1) Penggunaan tanda baca ada yang kurang tepat, bisa dilihat pada buku yang sudah diberi tanda, seperti misalnya penggunaan tanda titik, spasi.

2) Penulisan kata-kata ada yang kurang tepat, misalnya penggunaankata yang tidak baku, tertinggal satu huruf, kelebihan huruf, kesalahan penggunaan huruf yang seharusnya huruf $\mathrm{k}$ ditulis dengan huruf $\mathrm{c}$, misal penulisan diagnostic, seharusnya diagnostik, dan lain-lain.

3) Adajenis dan ukuran font yang berbeda, mungkin apakah lebih bagusnya disergamkan saja.

4) Ada penulisan istilah asing, harusnya miring penulisannya atau lebih baik ditulis bahasa Indonesianya saja.

5) Tentang catatan anekdot mungkin bisa diperjelas pengertiannya.

6) Penggunaan contoh pada catatan anekdot sepertinya kurang sinkron dengan keterangannya, bisa dicek halaman 40 .

Responden $3(\mathrm{NH})$
1) Mungkin lebih baik konsisten menggunakan kata yang sudah baku saja

2) Beberapa kata ada kesalahan pengetikan, bisa langsung dicek pada buku, sudah diberi tanda

Berdasarkan catatan-catatan dari responden tersebut, peneliti melakukan beberapa perbaikan pada bahan ajar

\section{3) Uji coba kelompok kecil}

Indikator acuan dalam Pelaksanaan uji coba kelompok kecil masih sama dengan uji coba perorangan. Pada tahap ini, peneliti ingin melihat tanggapan dari calon penguna bahan ajar tentang hasil revisi dari uji coba perorangan, apakah masih ada hal-hal yang perlu direvisi. Subjek uji coba dalam tahap ini berjumlah 7 orang yang merupakan mahasiswa PIAUD semester V kelas B.

Dari data hasil uji coba perorangan tersebut, dapat diketahui persentase jawaban dari responden. Untuk komponen kejelasan tulisan (jenis dan ukuran font), mendapat persentase 94,2\%, untuk komponen Kejelasan kalimat dan paragraph mendapat persentase $88,5 \%$, untuk komponen Kejelasan penggunaan contoh-contoh mendapat persentase 88,5\%, untuk komponen Kejelasan penggunaan ilustrasi mendapat persentase 


\begin{tabular}{|c|c|c|}
\hline \multicolumn{3}{|c|}{ Jurnal Warna : Jurnal Pendidikan Dan Pembelajaran Anak Usia dini. } \\
Maret 2020. Vol 05. No. 01 \\
\hline Received: Maret 2020 & Accepted: Maret 2020 & Published: Maret 2020 \\
\hline & Article DOI: 10.24903/jw.v5i1.436 \\
\hline
\end{tabular}

85,7\%,untuk komponen Kejelasan instruksi dalam tugas proyek dan post test medapar persentase $88,5 \%$, dan untuk komponen Membangkitkan motivasi mendapat persentase $100 \%$. Sebagaiman uji coba perorangan, persentase hasil uji kelompok kecil ini menunjukkan hasil yang sangat baik. Berikut beberapa catatan dan masukan dari para responden:

Responden 1 (Md):

1. Ada beberapa huruf yang tertinggal

2. Penulisan beberapa istilah kurang dipahami

3. Beberapa kata tidak dispasi (tergabung).

Responden 2 (SY):

1. Ada istilah-istilah yang kurang bisa dipahami.

Responden 3 (IH):

1. Penjelasan setiap materi mudah dipahami karena sudah disertai ilustrasi serta contoh-contoh yang sederhana

2. Ada beberapa kesalahan dalam penulisan dan penggunaan tanda baca.

Responden 4 (DR):

1. Penulisan huruf, spasi, tanda baca, banyak yang kurang tepat.

Responden 5 (NA):

1. Penggunaan kata-kata berbahasa asing, seperti kata skrining tes, library tourdi awal (pada tugas proyek) sedikit menyulitkan pengguna buku yang belum mengenal kata-kata ini. Namun penggunaan kata-kata seperti ini dapat menumbuhkan rasa ingin tahu pengguna buku yang berdampak pada munculnya usaha dari pengguna buku untuk mencari jawaban dari pertanyaan tersebut melalui membaca dan memahami materi pembelajaran.

2. Adanya beberapa definisi yang menggunakan Bahasa Inggris juga agak sedikit menyulitkan bagi pengguna buku dengan tingkatkemampuan Bahasa Inggris yang rendah. Namun budaya seperti ini perlu digalakkan di kalangan mahasiswa agar kemampuan Bahasa Inggris mereka miliki dapat terus berkembang dan terus mendapatkan stimulus melalui bacaanbacaan seperti ini.

3. Adapun mengenai isi buku, sudah lengkap dan dapat dipahami pengguna buku dengan mudah, karena penyajian materi disertai contoh-contoh yang mempermudah pengguna bukudalam memahmi materi. Ditambah lagi dengan rangkuman yang semakin memudahkan pengguna buku dalam menyimpulkan materi yang sedang dibahasa. 


\begin{tabular}{|c|c|c|}
\hline \multicolumn{3}{|c|}{ Jurnal Warna : Jurnal Pendidikan Dan Pembelajaran Anak Usia dini. } \\
Maret 2020. Vol 05. No. 01 \\
\hline Received: Maret 2020 & Accepted: Maret 2020 & Published: Maret 2020 \\
\hline & Article DOI: $10.24903 /$ jw.v5i1.436 \\
\hline
\end{tabular}

4. Peta konsep yang dibuat menjadi panduan/kata kunci yang harus benarbenar diingat pengguna buku dalam memahami materi yang sedang dibahas.

Responden $6(\mathrm{Az})$ :

1. Terdapat penulisan kata dan tanda baca yang salah.

2. Terdapat beberapa istilahyang masih belum saya pahami.

Responden 7 (Kh):

1. Longitudinal di halaman 17 bisa diperjelas maksudnya

2. Apakah ada nama lain dari running record

3. TPP maksudnya apa, Bu?

4. Kata-kata ada yang tersambung, tidak dispasi

Berdasarkan catatan-catatan dari responden tersebut, peneliti melakukan beberapa perbaikan pada bahan ajar. yang hampir semuanya memberikan masukan tentang pengetikan yang salah, penggunaan tanda baca, penggunaan kata baku, penggunaan istilah asing, dan penulisan sesuai kaidah Bahasa Indonesia yang benar. Jadi, pada tahap uji coba kelompok kecil ini tidak ada revisi pada bagian isi materi atau yang sifatnya substansial.

Masukan tentang penggunaan katakata asing yang masih belum dipahami oeh responden, peneliti melakukan revisi dengan memberikan garis miring pada kata yang pertama, sehingga pembaca sudah bisa memahami maksudnya. Untuk kelimat berikutnya, jika ada lagi penggunaan istilah asing tersebut, peneliti tidak lagi mencantumkan garis miringnya. Selebihnya peneliti melakukan revisi pada penulisan kata, huruf, tanda baca, spasi , dan hal lainnya yang terkait penggunaan Bahasa Indonesia yang sesuai kaidah.

\section{KESIMPULAN}

Penelitian ini telah menghasilkan sebuah bahan ajar yang berjudul asesmen perkembangan anak usia dini. Bahan ajar yang dikembangkan ini menggunakan model pembelajaran berbasis proyek atau Project Based Learning (PBL).

1. Prosedur pengembangan bahan ajar menggunakan model pengembangan Dick and Carey yang terdiri dari:

a. Identifikasi tujuan berdasarkan analisis kebutuhan

b. Melakukan analisis instruksional

c. Menganalisis perilaku yang diharapkan dan karakteristik pembelajar

d. Menentukan sasaran kinerja

e. Mengembangkan instrumen penilaian 


\begin{tabular}{|c|c|c|}
\hline \multicolumn{3}{|c|}{ Jurnal Warna : Jurnal Pendidikan Dan Pembelajaran Anak Usia dini. } \\
& Maret 2020. Vol 05. No. 01 \\
\hline Received: Maret 2020 & Accepted: Maret 2020 & Published: Maret 2020 \\
\hline & Article DOI: $10.24903 /$ iw.v5i1.436 \\
\hline
\end{tabular}

f. Mengembangkan strategi pembelajaran

g. Mengembangkan dan memilih Materi pembelajaran

h. Melakukan evaluasi formatif

i. Melakukan Revisi Produk

2. Dalam evaluasi formatif dilakukan beberapa pengujian, diantararanya uji validasi dari para ahli dan uji coba kepada calon pengguna.

a. uji validasi ahli terdiri dari dari ahli materi dan ahli desain pembelajaran. Berdasarkan indikator pada angket yang diserahkan kepada validator ahli, tidak ada yang perlu direvisi, namun ada beberapa catatan dari para ahli di luar indikator dalam angket, sehingga peneliti bisa melakukan revisi dari catatan tersebut.

b. uji coba calon pengguna terdiri dari uji coba perorangan dan ujicoba kelompok kecil. Uji coba perorangan dilakukan dengan memberikan angket kepada 3 orang mahasiswa. Terdapat beberapa saran dan masukan dari para responden.
Selanjutnya hasil revisi dari uji coba perorangan diuji coba lagi pada kelompok kecil yang berjumlah 7 orang mahasiswa. Pada uji coba kelompok kecil juga terdapatbeberapa catatan/ saran dari responden yang dijadikan panduan bagi peneliti untuk merevisi bahan aja

\section{DAFTAR PUSTAKA}

Barr, R., \& Tagg, J. (1995). From Teaching To Learning-A New Paradigm For Undergraduate Education. Change, 13-25.

Cocco, S. (2006). Student Leadership Development: The Contribution Of Project- Based Learning (Unpublished Master's Thesis). Royal Roads University, Victoria, BC, Canada

Hannafin, M. J., \& Hannafin, K. M. (2010). Cognition and student-centered, web-based learning: issues and implications for research and theory. In learning and instruction in the digital age (pp. 11-23). Springer US

Helle, L., Tynjälä, P., \& Olkinuora, E. (2006). Project-Based Learning In PostSecondary Education - Theory, Practice And Rubber Sling Shots. Higher Education

Jones, Leo. (2007). The Student-Centered Classroom. Cambridge University Press.

Markham, Thomas. (2011). Project Based Learning. Teacher Librarian, 39(2)

McCombs,B. \& Whistler, J. (1997). The Learnercentered Classroom And School: Strategies For Increasing Student Motivation And Achievement. San Francisco: JosseyBass Publishers.

Moffett, J., \& Wagner, B. J. (1992). StudentCentered Language Arts, K-12. 